\title{
ВЧИНЕННЯ ЗЛОЧИНУ ВІД ІМЕНІ ТА В ІНТЕРЕСАХ ЮРИДИЧНОЇ ОСОБИ ЯК ОБСТАВИНА, ЯКА ПІДЛЯГАЕ ДОКАЗУВАННЮ ДЛЯ ЗАСТОСУВАННЯ ЩОДО НЕЇ ЗАХОДІВ КРИМІНАЛЬНО-ПРАВОВОГО ХАРАКТЕРУ
}

\section{ПАНЬКО Мар'яна Свгенівна - аспірант кафедри кримінального права та процесу Львівського торговельно-економічного університету}

DOI:10.32782/LAW.2020.1.16

Рассмотреньи процессуальнье особенности привлечения к ответственности юридического лица в уголовном производстве. Акцентировано внимание на том, ито обстоятельства, являющиеся основанием для применения к юридическим лицам мер уголовно-правового характера, подлежат доказъванию в уголовном производстве. Поэтому в таких уголовных производствах доказвиванию подлежат как виновность фбзического лица в совершении инкриминируемого преступления, так и наличие оснований для применения мер уголовно-правового характера к юридическому личу.

Раскрытоо содержание оснований для применения мер уголовно-правового характера к юридическому личу. Проанализирована судебная практика. Сделан въвод, ито преступление может быть признано совершенным от имени юридического лица, если уполномоченное физическое личо действовало при этом именно как представитель юридического лица, то есть олицетворяло такое юридическое лицо и реализовъвала правосубгектность последнего. Определено методику и тактику сбора доказательств для установления наличия оснований для применения мер уголовно-правового характера в отношении юридического лица. Рассмотренъ особенности предоставления доступа к материалам досудебного расследования.

Ключевъе слова: юридическое лищо, в отношении которого осуществляется уголовное производство, мероприятия уголовно-правового характера, уполномоченное лицо.

\section{Постановка проблеми}

На підставі Закону України від 23 травня 2013 року № 314-VII «Про внесення змін до деяких законодавчих актів України щодо виконання Плану дій щодо лібералізації Европейським Союзом візового режиму для України стосовно відповідальності юридичних осіб», до КПК України (п.7 ч.1 ст. 91) та Загальної частини КК України (статті 96-1 - 96-10 Розділу XIV-1) були внесені зміни, в частині введення інституту заходів кримінально-правового характеру щодо юридичних осіб. Водночас, доводиться констатувати, що впровадження цього інституту поки що не дало очікуваного позитивного результату. Це пов'язано з тим, що у Сдиному державному реєстрі судових рішень міститься лише поодинокі вироки у яких би зазначалось про застосування заходів кримінально-правового характеру щодо юридичної особи. Втім органи досудового розслідування доволі часто звертаються до слідчих суддів з клопотанням про застосування арешту майна юридичних осіб. Однак в подальшому «справа далеко не заходить», оскільки суди зазвичай відмовляють у накладенні арешту на майно юридичної особи або ж знімають накладений арешт. 3 цього приводу справедливо зауважує О.Кравчук про те, що «відсутність порушення проваджень стосовно юридичної особи пов'язане з певною інертністю (традиційністю) процедури досудового розслідування, в якій нові методи і прийоми «приживаються» доволі повільно. Сторона обвинувачення не прагне «обтяжити» провадження додаткови- 


\section{Кримінальне право, кримінальний процес та криміналістика}

ми учасниками, зокрема, з мотивів процесуальної економії, або не має відповідної практики оформлення і доведення передбачених законом форм причетності юридичної особи до вчиненого злочину» [1, с.30]. Погоджуючись із позицією вищевказаного автора, водночас, слід вказати й на те, що відсутність практики застосування щодо юридичних осіб заходів кримінально-правового характеру можна пояснити власне також і тим, що у КК України недостатньо чітко регламентовані підстави застосування цього інституту, що створює труднощі у процесі доказування обставин, які є підставою для застосування щодо юридичних осіб заходів кримінальноправового характеру.

\section{Стан дослідження}

Деякі кримінально-процесуальні дослідження висвітлюють тільки фрагментарно окремі питання, які пов'язані з доказуванням обставин, які є підставою для застосування щодо юридичних осіб заходів кримінальноправового характеру. Так, одні автори розглядали це поняття через призму предмета доказування у кримінальному провадженні [2; 3], процесуальних аспектів застосування цього інституту [4; 5], інші - вивчали міжнародне співробітництво у кримінальних провадженнях щодо юридичних осіб [6].

Втім на сьогодні база знань не піддавалась аналізу на предмет ступеню наукового забезпечення процесу доказування обставин, які є підставою для застосування щодо юридичних осіб заходів кримінально-правового характеру. Здебільшого науковці розглядали лише окремі аспекти цього питання в рамках наукових статей, у науково-практичних коментарях до КПК України чи доповідях на конференціях.

Таким чином, основною метою цієї статті є з'ясування особливостей вчинення злочину від імені та в інтересах юридичної особи як обставини, яка підлягає доказуванню для застосування щодо неї заходів кримінальноправового характеру.

\section{Виклад основних положень}

У законодавчому порядку не розкритий зміст поняття вчинення злочину «від імені юридичної особи», що вочевидь є недоліком законодавчої техніки. Така відсутність нормативного визначення не так уже й безневинна, оскільки породжує різні підходи до розуміння цієї умови, а відтак ускладнює процес доказування в цій частині. В.К. Грищук та О.Ф. Пасєка зазначають, що вчинення дій від імені юридичної особи означає, що фізична особа має право виражати волю юридичної особи щодо виникнення, зміни чи припинення ії прав та обов'язків. Втім, на думку цих науковців більшість службовців, працівників юридичної особи - не більш ніж ії «члени» чи «руки», котрі виконують певний обсяг роботи. Відтак про них не можна сказати, що вони діють свідомо від імені юридичної особи [7, с.280; с.146-147]. На думку К.П. Задої законодавець закріпив у КК України так звану «субститутивну відповідальність» (vicariousliability) або іншими словами відповідальність за «чуже» діяння [8, с.49-50]. Така позиція не позбавлена раціонального зерна, оскільки юридичні особи не дають уповноваженим особам «довіреності» на вчинення злочину. Окрім того, навряд чи в їх установчих документах передбачено положення про те, що метою чи предметом їх діяльності 6 вчинення уповноваженою особою злочину від імені юридичної особи. Разом із тим, відповідно до ч. 1 ст. 1172 Цивільного кодексу України юридична особа відшкодовує шкоду, завдану їхнім працівником під час виконання ним своїх службових обов'язків. Окрім того, уповноважені представники юридичної особи та їі одноособові чи колегіальні органи можуть від ії імені набувати права та виконувати відповідні обов'язки (ч.2 ст.92 ЦК України). Слід погодитись з позицією А.С. Нікіфорова, який стверджує, що юридична особа делегує своєму керівному органу прийняття та виконання основних стратегічних і оперативних рішень від свого імені. Відповідно, рішення і засновані на них дії за своєю юридичною суттю ототожнюються 3 рішеннями та діями юридичної особи. За дії свого керівного органу та за наслідки цих дій юридична особа також повинна підлягати безпосередньо відповідальності. Тобто, злочин визнається вчиненим юридичною особою, якщо він вчинений безпосередньо або за посередництва інших осіб, особою або особами, які контролюють вчинення юридичною особою 
своїх прав і діють у вчинення цих прав, тобто $\epsilon$ alterego юридичної особи, його «іншим я» [9, с. 65]. Таким чином можна вважати, що злочин слід вважати вчиненим від імені юридичної особи, якщо уповноважена особа, використовуючи надані їй повноваження, реалізовувала правосуб'єктність підприємства, установи чи організації.

Наступною умовою на підставі якої можуть бути застосовані заходи кримінальноправового характеру щодо юридичної особи, є вчинення уповноваженою особою злочину в іiі інтересах. У ЦК України передбачений припис відповідно до якого орган або особа, яка відповідно до установчих документів юридичної особи чи закону виступає від іiі імені, зобов'язана діяти в інтересах юридичної особи, добросовісно і розумно та не перевищувати своїх повноважень (ч.3 ст.92). Відповідно до п.2 примітки до ст.96-3 КК України злочини, визнаються вчиненими в інтересах юридичної особи, якщо вони призвели до отримання нею неправомірної вигоди або створили умови для отримання такої вигоди, або були спрямовані на ухилення від передбаченої законом відповідальності.

Насамперед, необхідно з'ясувати, що слід розуміти під поняттям «інтерес». Власне це питання було предметом розгляду Конституційного Суду України у справі від 1 грудня 2004 р. № 18-рп/2004 щодо офіційного тлумачення окремих положень частини першої статті 4 Цивільного процесуального кодексу України (справа про охоронюваний законом інтерес). КСУ у своєму рішенні зазначив, що «у загальносоціологічному значенні категорія «інтерес» розуміється як об'єктивно існуюча і суб'єктивно усвідомлена соціальна потреба, як мотив, стимул, збудник, спонукання до дії; у психології - як ставлення особистості до предмета, як до чогось для неї цінного, такого, що притягує. В юридичних актах термін «інтерес», враховуючи його як етимологічне, так і загальносоціологічне, психологічне значення, вживається у широкому чи вузькому значенні як самостійний об'єкт правовідносин, реалізація якого задовольняється чи блокується нормативними засобами» (п.3.1) [10].

Видається, інтереси юридичної особи повинні випливати із мети та завдань ії діяльності, а відтак бути зафіксованими у ста- тутних документах підприємства, установи, організації. У зв’язку з цим необхідно визначитись в яких саме документах містяться відомості про вчинення злочину від імені та в інтересах юридичної особи, які способи їх отримання, а також яким чином здійснюється їх дослідження. Власне такий перелік документів $\epsilon$ достатньо широкий та залежить від виду діяльності юридичної особи, а відтак від злочинного посягання, яке здійснюється від іï імені та в її інтересах. Так, наприклад, у випадку легалізації (відмиванні) доходів, одержаних злочинним шляхом (ст.209 КК України) чи використанні коштів, здобутих від незаконного обігу наркотичних засобів, психотропних речовин, їх аналогів, прекурсорів, отруйних чи сильнодіючих речовин або отруйних чи сильнодіючих лікарських засобів (ст.306 КК України) такими документами будуть: відомості про рух коштів на банківських рахунках юридичної особи, їі уповноважених осіб та підприємств, установ чи організацій, за допомогою яких вчинялись злочинні дії по легалізації; платіжні доручення, товарно-транспортні накладні, митні декларації, акти прийому-передачі виконаних робіт, розрахункові чеки тощо. Зазначені документи можуть зберігатися у банківських установах, за місцем знаходження юридичної особи, від імені та в інтересах якої вчиняється злочин, а також перебувати у володінні інших юридичних та фізичних осіб, задіяних у легалізації доходів, здобутих злочинним шляхом. А тому їх необхідно вилучити в ході здійснення тимчасового доступу до речей та документів, а також обшуку.

У випадку вчинення корупційних злочинів (ст.368-3, ст. 368-4, ст. 369, ст. 369-2 КК України) такими можуть бути документи, які надавалися уповноваженою особою юридичної особи під час здійснення підкупу службової чи іншої особи для вчинення останньою дій в інтересах юридичної особи. Наприклад, для участі у тендері уповноважена особа юридичної особи надає цінову пропозицію, кошторис, довідку, що посадова особа учасника уповноважена представляти інтереси юридичної особи, довідку, що учасник не визнаний в установленому законом порядку банкрутом і щодо нього не відкрита ліквідаційна процедура тощо. В подальшому з метою пере- 


\section{Кримінальне право, кримінальний процес та криміналістика}

моги у тендері пропонує неправомірну вигоду службовій особі тендерного комітету. Відтак, у поданих документах буде міститися інформація, що уповноважена особа діяла від імені та в інтересах юридичної особи.

Такі документи можуть знаходитись безпосередньо в установі, яка оголосила про проведення тендеру, в уповноваженої особи юридичної особи або передані особі щодо якої здійснюється підкуп. У першому випадку орган досудового розслідування, як сторона кримінального провадження, вправі здійснити тимчасовий доступ до тендерної документації з подальшим іï вилученням. Якщо ж вказані документи знаходяться в уповноваженої особи юридичної особи або в особи щодо якої здійснюється підкуп, то вони можуть бути вилучені слідчим, прокурором під час проведення обшуку приміщень, транспортних засобів, іншого володіння осіб, в якому знаходяться відповідні особи, обшуку затриманої особи або оглядів місця події. Окрім того, орган досудового розслідування, здійснюючи безпосереднє переслідування підозрюваної особи (уповноваженої особи), у відповідності до ч.3 ст. 233 КПК України вправі провести обшук володіння особи без ухвали слідчого судді, в ході якого може здійснити вилучення записників (так званих «чорнових записів, чорної бухгалтерії») та інших документів у яких може містись інформація про вчинення злочину від імені та в інтересах юридичної особи.

Перевірку вилучених документів органу досудового розслідування необхідно здійснити 3 метою встановлення наступних обставин: чи діяла уповноважена особа від імені та в інтересах юридичної особи; хто видав відповідний документ та які дії за допомогою нього були вчиненні уповноваженою особою в інтересах юридичної особи. Така перевірка проводиться шляхом проведення огляду вилучених документів, проведення експертиз (почеркознавчих, технічних експертиз документів, експертиз документів бухгалтерського, податкового обліку і звітності, експертиз документів фінансово-кредитних операцій, експертиз документів про економічну діяльність підприємств й організацій тощо). Окрім того, важливим аспектом у дослідженні вилучених документів 6 проведення доку- ментальних перевірок, ревізій, аудитів. Така перевірка, як правило, здійснюється підрозділами Державної аудиторської служби, Державної податкової служби. Також у деяких органів наявні підрозділи внутрішнього аудиту, зокрема, в МВС, МОУ, СБУ тощо.

У чинному КПК України передбачено право сторони обвинувачення здійснювати витребування висновків ревізій та актів перевірок. Водночас доводиться констатувати, що у ньому відсутній механізм призначення проведення позапланових документальних перевірок юридичних осіб. На підставі ЗУ «Про прокуратуру» від 14 жовтня 2014 р. № 1697-VII виключено повноваження слідчого щодо призначення проведення ревізій та перевірок, яке регламентувалося положеннями п.4 ч.2 ст.40 КПК України. У зв'язку $з$ цим призначення позапланової документальної перевірки (ревізії) здійснюється виключно за рішенням суду. Втім судова практика в цій частині $є$ неоднозначною. Так, Колегією суддів судової палати з розгляду кримінальних справ Київського апеляційного суду від 10 грудня 2018 р. було прийнято рішення скасувати ухвалу слідчого судді Солом'янського районного суду м. Києва від 30.11.2016, якою задоволено клопотання старшого слідчого та призначено у кримінальному провадженні позапланову перевірку з питань дотримання вимог податкового законодавства України. В обгрунтування свого рішення колегія суддів зазначає наступне. Частиною 1 ст. 309 КПК України визначений перелік ухвал слідчого судді, які можуть бути оскаржені в апеляційному порядку. Серед цього переліку відсутні ухвали слідчого судді про призначення позапланової перевірки 3 питань дотримання вимог податкового законодавства. Однак ця обставина не виключає можливості оскарження такої ухвали, із урахуванням того, що призначення слідчим суддею зазначеної перевірки нормами КПК не передбачено, у зв'язку із чим такого роду ухвали не могло бути у переліку, передбаченому ч. 1 ст. 309 КПК України [11].

Водночас в іншій справі ухвалою слідчого судді Святошинського районного суду м. Києва від 21 квітня 2017 р. у кримінальному провадженні за ознаками вчинення злочинів, передбачених ч.1 ст.205, ч.1 ст.209 КК Укра- 
їни, прийнято рішення про задоволення клопотання слідчого та призначено позапланову документальну перевірку з питань дотримання вимог податкового законодавства ПП «АСТЕРІЯ ТРЕЙД» стосовно повноти, своєчасності нарахування та сплати податку на додану вартість за наслідками фінансовогосподарських взаємовідносин із ТОВ «РАЙДЕК» (ТОВ «Еврохоумс»), ТОВ «АЛЬФА ДІНК» (за весь період діяльності [12]. Таке рішення суду є безпідставним, оскільки у слідчого були відсутні правові підстави щодо подачі такого клопотання, а слідчий суддя не повинен був ухвалювати відповідне рішення з огляду на те, що у КПК України не передбачено порядку розгляду таких клопотань. А тому, видається, необхідно внести відповідні зміни до чинного законодавства, передбачивши в Розділі II «Заходи забезпечення кримінального провадження» КПК України, такий захід як призначення проведення ревізій (аудитів), та інших перевірок.

Результат дослідження зазначених документів надасть можливість органу досудового розслідування визначити можливих свідків, потерпілих та підозрюваних у кримінальному провадженні з метою подальшого отримання їх показань. Так, органом досудового розслідування можуть бути допитані працівники юридичної особи з метою встановлення обставин чи діяла відповідна уповноважена особа від іiі імені та в її інтересах. Підлягають допиту як свідки інші особи, з якими уповноважена особа юридичної особи контактувала в період вчинення злочину. Для встановлення обставини чи вчинено злочин від імені та в інтересах юридичної особи, підлягають з'ясуванню наступні питання: які обставини відомі про уповноважену особу юридичної особи; яку інформацію про себе останній повідомляв; спектр його діяльності; що відомо про відповідну юридичну особу; які дії уповноважена особа вчиняла на користь юридичної особи; яку мету переслідувала уповноважена особа, вчиняючи певні дії тощо.

\section{Висновки}

Таким чином вивчення поняття та підстав застосування щодо юридичних осіб заходів кримінально-правового характеру виступають основою для формування праців- никами правоохоронних органів уявлень про обставини, які повинні бути встановлені під час проведення системи слідчих (розшукових) та негласних слідчих (розшукових) дій та інших процесуальних дій, що сприяє вибору оптимальних методів боротьби зі злочинністю.

\section{入ітература}

1. Кравчук О. Перспективи кримінальної відповідальності юридичних осіб за корупційні злочини. Застосування заходів кримінально-правового характеру щодо юридичних осіб: матеріали міжнародного круглого столу (30 липня 2019 року). Київ: Національна академія прокуратури України, 2019. - С. 30-33

2. Жовтан П.В. Предмет доказування у кримінальному провадженні про прийняття пропозиції, обіцянки або одержання неправомірної вигоди службовою особою / П.В. Жовтан // Боротьба з організованою злочинністю та корупцією: теорія і практика. - №2 (33) - 2014 p. - C.50-53

3. Форостяний А.В. Щодо розширення предмета доказування у кримінальному провадженні / А.В. Форостяний // Юридична наука. - №3 - 2015 р. - С.152-158

4. Михайленко В. Процесуальні аспекти інституту заходів кримінально-правового характеру щодо юридичної особи в сучасних умовах правового регулювання. Застосування заходів кримінально-правового характеру щодо юридичних осіб: матеріали міжнародного круглого столу (30 липня 2019 року). Київ:Національна академія прокуратури України, 2019. - С.72-77

5. Скок О., Шевченко Т. Деякі питання щодо застосування заходів кримінально-правового характеру до юридичних осіб; Застосування заходів кримінально-правового характеру щодо юридичних осіб: матеріали міжнародного круглого столу (30 липня 2019 року). Київ:Національна академія прокуратури України, 2019. - С.78-80

6. Ахтирська Н. Міжнародне співробітництво у кримінальних провадженнях щодо юридичних осіб (законодавчий та організаційні аспекти). Застосування заходів кримінально-правового характеру щодо юридичних осіб: матеріали міжнародного круглого 


\section{Кримінальне право, кримінальний процес та криміналістика}

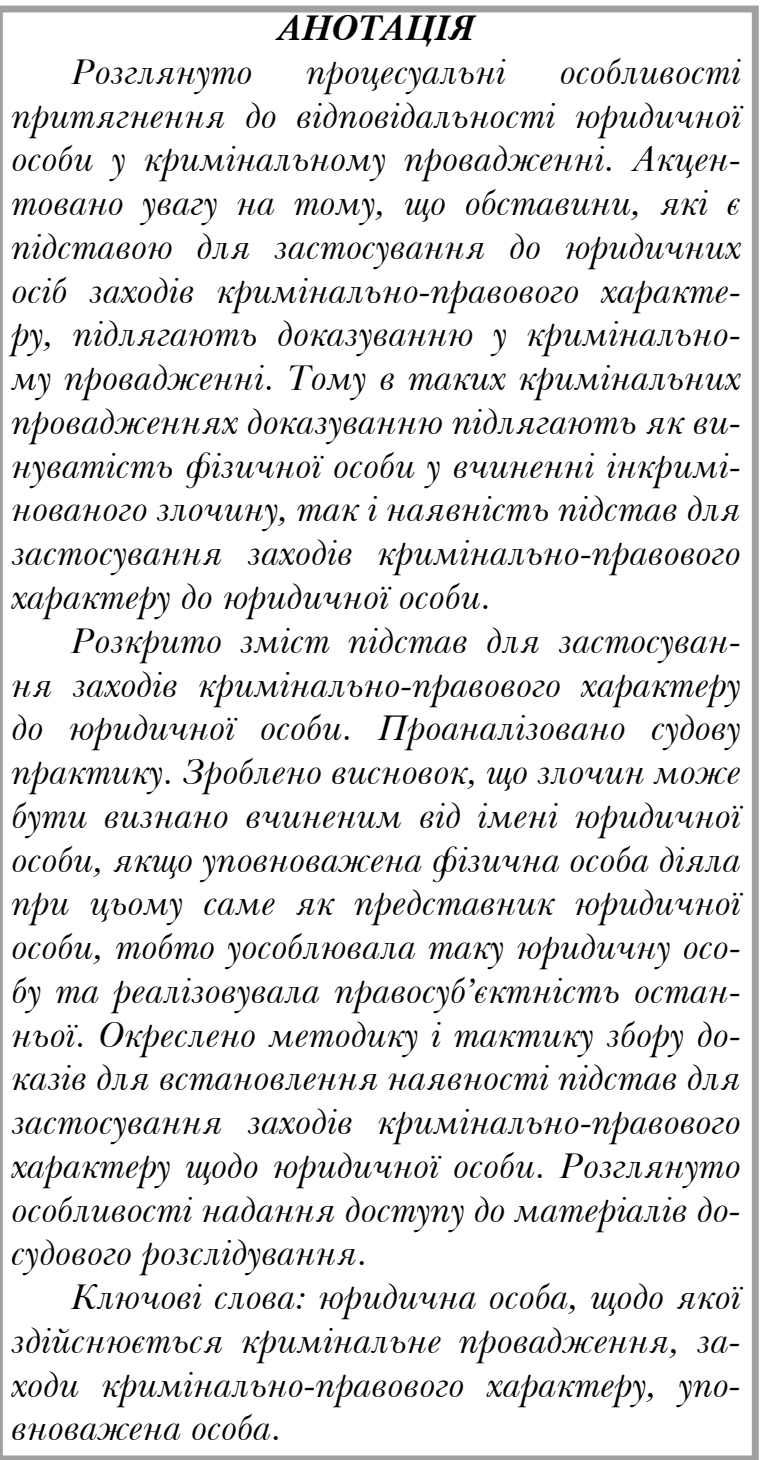

столу (30 липня 2019 року). Київ:Національна академія прокуратури України, 2019. - С.2125

7. Грищук В.К. Кримінальна відповідальність юридичних осіб: міжнародний досвід та основні теоретичні підходи: наук.-практ. посіб. / В.К. Грищук, О.Ф. Пасєка. - Київ: Юрінком Інтер, 2017. - 296 с.

8. Задоя К.П. Правова природа заходів кримінально-правового характеру, що застосовуються до юридичних осіб / К.П. Задоя // Право і громадянське суспільство. - №4. 2014 p. - C. $42-53$

9. Никифоров А.С. Современные тенденции развития уголовного законодательства и уголовно-правовой теории / А.С. Никифоров // Государство и право. - 1994. - № 6. - С. 65-

\section{SUMMARY}

In the article are considered procedures features of responsibility of legal entitie in criminal proceeding. The author pays attention on that circumstances that are founding for application to the legal entities of measures of criminal law character and are subjects to proof in criminal proceedings. Therefore, in such criminal proceedings, evidence of the guilt of an individual in committing an incriminated crime, as well as the existence of grounds for the application of criminallaw measures to a legal entity.

The article discloses the content of the grounds for applying the measures of criminal law to a legal entity. Analyzed yudicial practice. It is concluded that the crime can be recognized as committed on behalf of a legal entity if the authorized individual acted as a representative of the legal entity, that is, personified such a legal entity and realized the legal personality of the latter, and did not act privately, acting on its own behalf. The methodology and tactics for collecting evidence to establish the grounds for applying measures of criminal law to a legal entity are defined. Features of providing access to materials of pre-trial investigation are considered.

Key words: legal entity, which is subject to criminal proceedings, measures criminal-law, authorized person.

68.

10. Рішення Конституційного Суду України від 1 грудня 2004 р. № 18-рп/2004 у справі за конституційним поданням 50 народних депутатів України щодо офіційного тлумачення окремих положень частини першої статті 4 Цивільного процесуального кодексу України (справа про охоронюваний законом інтерес)URL: https://zakon.rada.gov.ua/laws/ show/v018p710-04

11. Колегія суддів судової палати з розгляду кримінальних справ Київського апеляційного суду від 10 грудня 2018 р. Справа № 760/19091/16-к [Електронний ресурс]. URL: http://www.reyestr.court.gov.ua/Review/ $\underline{78516483}$

12. Ухвала слідчого судді Святошинського районного суду м. Києва від 21 квітня 2017 p. Справа № 1-кс/759/1382/17. [Електронний pecypc]. URL: http://www.reyestr.court.gov.ua/ $\underline{\text { Review/66432080 }}$ 